\title{
Myxobolus intrachondrealis sp. n. (Myxosporea: Myxobolidae), a parasite of the gill cartilage of the common carp, Cyprinus carpio
}

\author{
Kálmán Molnár \\ Veterinary Medical Research Institute, Hungarian Academy of Sciences, P. O. Box 18, H-1581 Budapest, Hungary
}

Key words: Myxozoa, Myxobolus, new species, gill cartilage, histology

\begin{abstract}
A species not identifiable with any of the about 23 Myxobolus species recorded from the common carp so far, was detected in the gills of one- and two-summer-old specimens of the common carp (Cyprinus carpio L.) cultured in pond farms in Hungary. The strictly tissue-specific plasmodia of the parasite were located, surrounded by hyaline cartilage cells, in the chondrous substance of the terminal parts of the gill arches and in the cartilage structure ventrally connecting the gill arches. The spores of the parasite described as Myxobolus intrachondrealis sp. n. developed in globular or ellipsoidal plasmodia measuring 300-600 $\mu \mathrm{m}$. By their elongated ellipsoidal shape and similarly elongated polar capsules the spores were well distinguishable from the hitherto described Myxobolus species parasitic in the common carp and also from the cartilage-parasitic Myxobolus species of other fishes.
\end{abstract}

Of all fish species, the common carp (Cyprinus carpio L.) can be considered to have the best studied parasite fauna. Thus, it is surprising that hitherto unrecorded parasites of this fish species are being discovered even today. In the past decades the parasite fauna of the common carp subspecies cultured in Europe (Cyprinus carpio carpio) increased primarily through the introduction of parasites of Cyprinus carpio haematopterus indigenous in the Far East (Bauer and Hoffman 1976, Molnár and Kovács-Gayer 1981-1982), but a Myxobolus species infecting the cartilage of the common carp has not been known from the Far East. The number of myxosporean species parasitising the common carp is very high. In their review of the genus Myxobolus, Landsberg and Lom (1991) listed 23 species recorded in common carp, the majority of which were described from the Far-Eastern common carp subspecies by Japanese, Russian and Chinese authors (Kudo 1917, Hoshina 1953, Akhmerov 1960, Chen 1973, Yukhimenko 1986). Only four Myxobolus species, the muscle parasite M. cyprini Doflein, 1898, M. dispar Thélohan, 1895 forming plasmodia on the gill filaments, M. basilamellaris Lom et Molnár, 1983 colonising the base of the gill filaments, and M. encephalicus (Mulsow, 1911) developing in the brain, are known to occur in common carp cultured in Hungary (Molnár and Szakolczai 1980, Lom and Molnár 1983). Apart from data given in a few general faunistic works, besides the above species only $M$. dogieli BykhovskayaPavlovskaya et Bykhovski (Bauer et al. 1991) could be demonstrated to occur in other countries of Europe. The host, organ and tissue specificity of myxosporean species represents a less well studied and rather neglected area. According to Molnár (1986), members of the genus Myxobolus have relatively strict host specificity and are characterised by expressed tissue specificity. At the same time, in the case of Myxobolus species found in fishes of the Soviet Union, Donec and Shulman (1984) listed more than 40 hosts for a given parasite species, and considered it possible that these parasites could colonise diverse organs of the hosts. On the other hand, Molnár and Kovács-Gayer (1985) have proved that $M$. cyprini, a species earlier considered to have low organ specificity, is actually a strict muscle parasite, and that its spores detectable throughout the body get to the site of location only after disruption of the plasmodium.

This paper describes a new Myxobolus species from the common carp by the name $M$. intrachondrealis based upon its typical location in the gill cartilage and the morphological characteristics of the spores.

\section{MATERIALS AND METHODS}

One- and two-summer old common carp specimens submitted to the laboratory from different fish farms of Hungary were examined. The primary objective of examination was to collect spores of some gill-parasitic myxosporean species (Myxobolus dispar, M. basilamellaris, Sphaerospora molnari). The fish were transported to the laboratory alive, and the one-summer specimens were kept in aerated aquaria while the two-summer-old ones in tanks of flow-through system. The work was conducted on a continuous basis in 1998 and 1999, depending on the availability of fish. The fish were killed by decapitation, bled, and their gills were examined for the occurrence of myxosporean plasmodia under a dissecting microscope. Small pieces of gill filaments from the same gills were also examined under coverslip in a compound microscope to detect solitary spores (Myxobolus cyprini, M. encephalicus, Thelohanellus hovorkai). Primarily the gill filaments were screened; however, after observing the first cartilage parasite the gill arch and the cartilaginous structures connected to it 
were also examined. The cartilaginous structure and its parts were first examined in a stereomicroscope, and then segments of different refraction and supposedly containing plasmodia were studied also under a coverslip in a compound microscope. To collect spores from the mature plasmodia, the infected cartilage segment was cut through with a razor blade, the released spores were dispersed in a small volume of $0.6 \%$ saline solution, placed under a coverslip, and their morphological characteristics were studied. Spore dimensions were also determined on the basis of freshly released spores placed under coverslip. Permanent preparations were made by placing a portion of spores into glycerol-gelatine and mounting them under a coverslip. Spores were recorded with the help of a video image program on videotapes as described by Székely (1997). For histology, a part of the infected cartilage containing plasmodia was fixed in Bouin's solution for 4 hours, embedded in Paraplast ${ }^{\mathbb{R}}$ wax, cut into 4 to $8 \mu \mathrm{m}$ thick sections, and stained with haematoxylin and eosin.

\section{RESULTS}

The plasmodia of the parasite were detected from the gills of one- and two-summer common carp cultured in pond farms in 1998. Six out of 24 one-summer carp proved to be infected, and the 2 two-summer specimens examined also showed infection. According to the survey repeated in the early spring of 1999, this parasite occurred in 4 out of 7 fish farms surveyed and infected $34 \%$ of the 400 one- and two-summer carp specimens examined. The small globular plasmodia 300-500 $\mu \mathrm{m}$ in diameter and the small ellipsoidal plasmodia measuring 400-600 × 250-350 $\mu \mathrm{m}$ were detected primarily in the dorsal and ventral ends of the gill arches, in the compact substance composed exclusively of cartilage and devoid of blood vessels. Less often they could be found also in other parts of the cartilaginous gill arch and in the cartilage structure (symplectinum) ventrally connecting the wall of the gill cavity with the hemibranchia. Under microscope the plasmodia were distinguishable from the transparent cartilaginous substance by their lighter colour. After cutting through the infected cartilage part, 3,000 to 10,000 spores were released from each cyst. The central part of plasmodia found in July was filled by spores and their peripheral parts by developing sporogonic stages. Fish dissected between September and mid-April already contained mature spores only. The majority of plasmodia contained spores of regular ellipsoidal shape (Fig. 1); however, from a few, possibly over-mature, plasmodia deformed spores of elongated shape (Fig. 2) could be released. Simultaneously with the infection of cartilage, the plasmodia of $M$. basilamellaris were detectable in the connective tissue of the gill arch at the base of the gill filaments, and often the large plasmodia of $M$. dispar were also present in the central part and at the end of the gill filaments as mixed infection. The spores of the latter two species were easily distinguishable in shape and structure from those of the cartilage-parasitic Myxobolus species, which is described as a new species as follows.

Myxobolus intrachondrealis sp. $\mathrm{n}$.

Figs. 1-3

Description of vegetative stages. No young plasmodia found. More developed plasmodia containing late sporogonic stages and mature spores of globular to ellipsoidal shape. Globular plasmodia $300-500 \mu \mathrm{m}$ in diameter, while ellipsoidal plasmodia 400-600 $\mu \mathrm{m}$ long $\times 250-300 \mu \mathrm{m}$ wide.
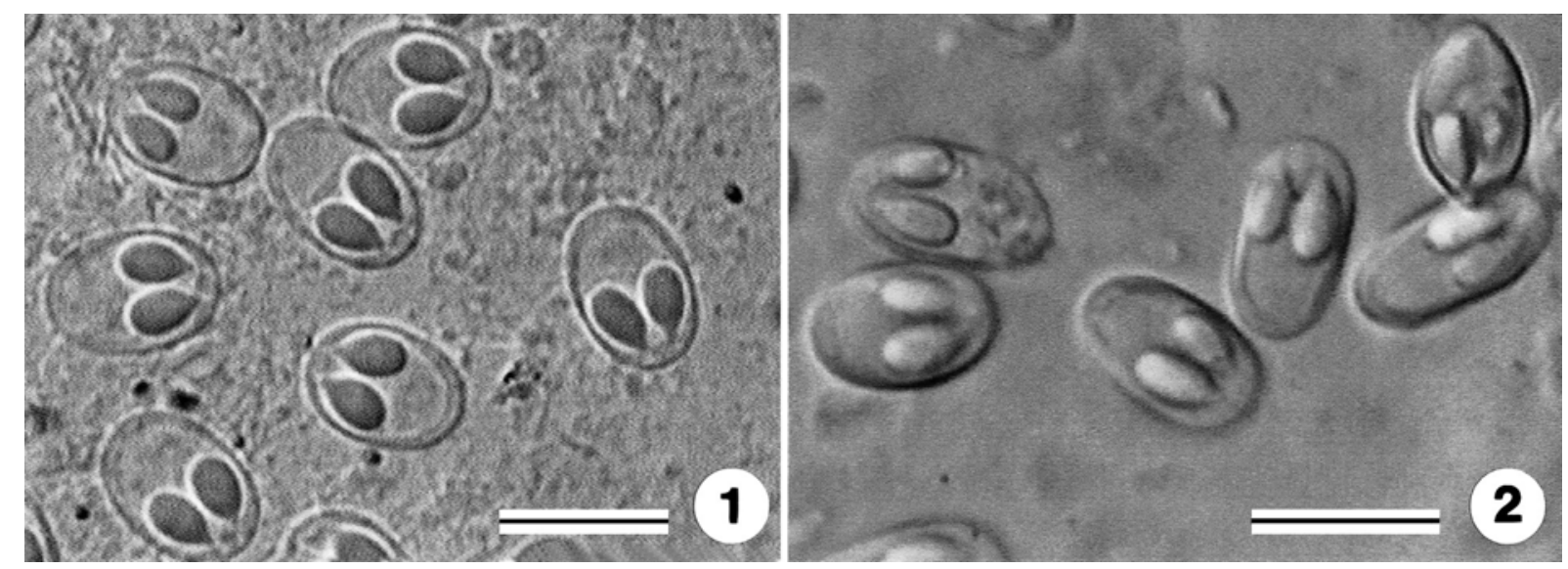

Figs. 1, 2. Myxobolus intrachondrealis sp. n. Fig. 1. Spores freed from a plasmodium. Video image. Fig. 2. Degenerated spores freed from an aged plasmodium. Video image. Scale bars $=10 \mu \mathrm{m}$. 

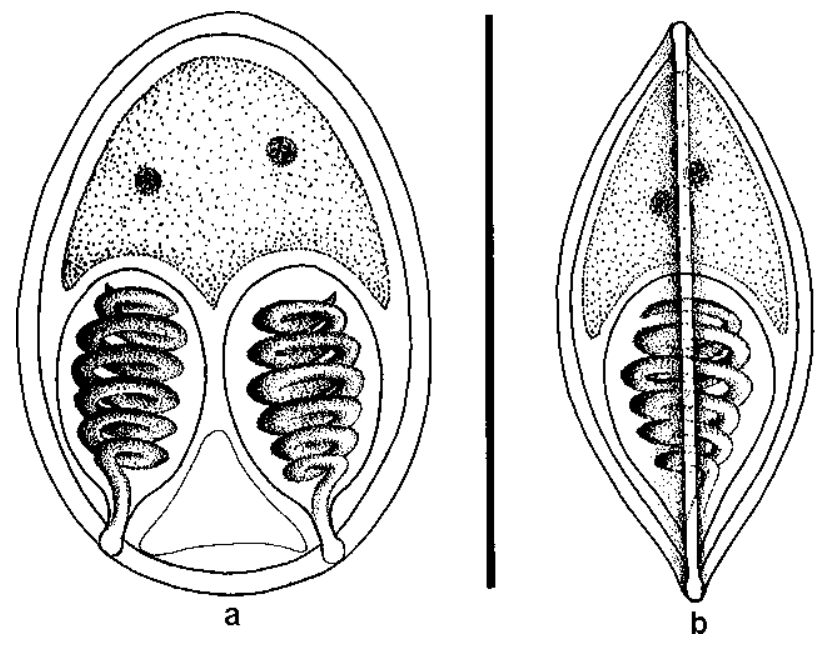

Fig. 3. Schematic illustration of Myxobolus intrachondrealis sp. $n$. $\mathbf{a}-$ spore in frontal view; $\mathbf{b}-$ spore in lateral view. Scale bar $=10 \mu \mathrm{m}$.

Description of spores (based on 50 spores from fully matured plasmodia): Spores (Figs. 1, 3) elongated ellipsoidal in frontal view and discus-shaped in lateral view. Spore valves relatively thin, symmetrical and smooth. Sutural line indistinct, sutural edge less protruding. Spores $10.2(9.0-11) \mu \mathrm{m}$ in length, 6.5 (6-7) $\mu \mathrm{m}$ in width and 4 (3.7-4.2) $\mu \mathrm{m}$ in thickness. Two polar capsules elongated pyriform in shape, equal in size, 4.5 (3.7-4.7) $\mu \mathrm{m}$ long and $2.2(2-2.6) \mu \mathrm{m}$ wide. Polar capsules lie in the spores almost parallel and open at the base of the intercapsular appendix. Polar filaments closely coiled with 9 to 11 turns in the polar capsule, situated perpendicularly to the longitudinal axis of the capsule. An indistinct, triangular intercapsular appendix is located between the polar capsules at the anterior end of the spore. No iodinophilous vacuole discernible in the sporoplasm of the spores.

Deformed spores obtained from the over-mature plasmodia were elongated ellipsoidal and laterally flattened (Fig. 2), 11-12.5 $\mu \mathrm{m}$ long by $6-6.5 \mu \mathrm{m}$ wide. These spores contained a shrunken sporoplasm of indistinct structure.

T y p e hos t: Cyprinus carpio L.

L o c a 1 i t y : Fish farms of Hortobágy (Eastern Hungary) and Szarvas (Southeast Hungary); other fish farms in Hungary.

S it e of infection: Cartilage of the gill arches.

$\mathrm{T}$ y $\mathrm{p} \mathrm{e} \mathrm{m}$ a $\mathrm{t}$ e $\mathrm{r}$ i a 1 : Spores have been deposited in the protozoological collection of the Hungarian Natural History Museum, Budapest.

E t y m o log y: The name of the parasite derives from the location of plasmodia.

Differential diagnosis. Regarding its morphology and location within the host, $M$. intrachondrealis is easily distinguishable from the 23 Myxobolus species known from the common carp (Donec and Shulman 1984, Dyková and Lom 1988, Landsberg and Lom 1991, Lom and Dyková 1992). The elongated ellipsoidal spores of $M$. intrachondrealis markedly differ from the rounded spores of most of the latter species. Based upon spore shape and the insignificant intercapsular appendix, of the species known from common carp the spores of the new species resemble Myxobolus cyprinicola Reuss, 1906 the most, but differ from the latter by their much more elongated polar capsules and by the absence of iodinophilous vacuole from the sporoplasm. The spores of $M$. intrachondrealis resemble also Myxobolus cultus Yokoyama, Ogawa et Wakabayashi, 1995, but differ from it by the more elongated shape of the polar capsules and by the large number of their closely coiled polar filaments. From Myxobolus dispar Thélohan, 1895 and Myxobolus basilamellaris Lom et Molnár, 1985 most commonly occurring in the gills of common carp, $M$. intrachondrealis differs by its elongated ellipsoidal spores and by its longer and equal polar capsules. From the typical cartilage-parasitic species Myxobolus cerebralis Hofer, 1903, Myxobolus cartilaginis (Hoffman, Putz et Dunbar, 1965) and Myxobolus sharpeyi Molnár, Masoumian et Abasi, 1996 having a spherical spores, $M$. intrachondrealis can be differentiated by its more elongated shape.

Histological findings. The globular or ellipsoidal plasmodia were located in the cartilaginous substance of the gill arches and the osseous plate connecting them, surrounded by typical hyaline cartilage cells (Figs. 4, 5). The thin, eosinophilic ectoplasm of the plasmodium was located immediately next to the chondrocytes. Younger plasmodia located within the ectoplasm contained a layer consisting of sporogonic stages and intensely staining with haematoxylin, while centrally mature spores were found (Fig. 4). In mature plasmodia, only a very thin layer consisting of pansporoblasts adhered closely to the ectoplasm, and the plasmodia were filled by masses of spores. No capsule of host origin could be observed between the plasmodium and the chondrocytes, and the plasmodium was connected with the surrounding chondrocytes without signs indicative of a host reaction. Occasionally, several plasmodia were seen side by side. In one case, infection was detected in two joining parts of the cartilaginous structure of a gill arch, so that the plasmodia caused distinct lesions in both halves of the cartilage (Fig. 6).

\section{DISCUSSION}

About 460 Myxobolus species are known at present, which include numerous synonyms. In addition, it is likely that some Myxobolus spores collected from nonspecific hosts and from organs different from the original location have been erroneously identified with better-known parasite species. The most conspicuous 

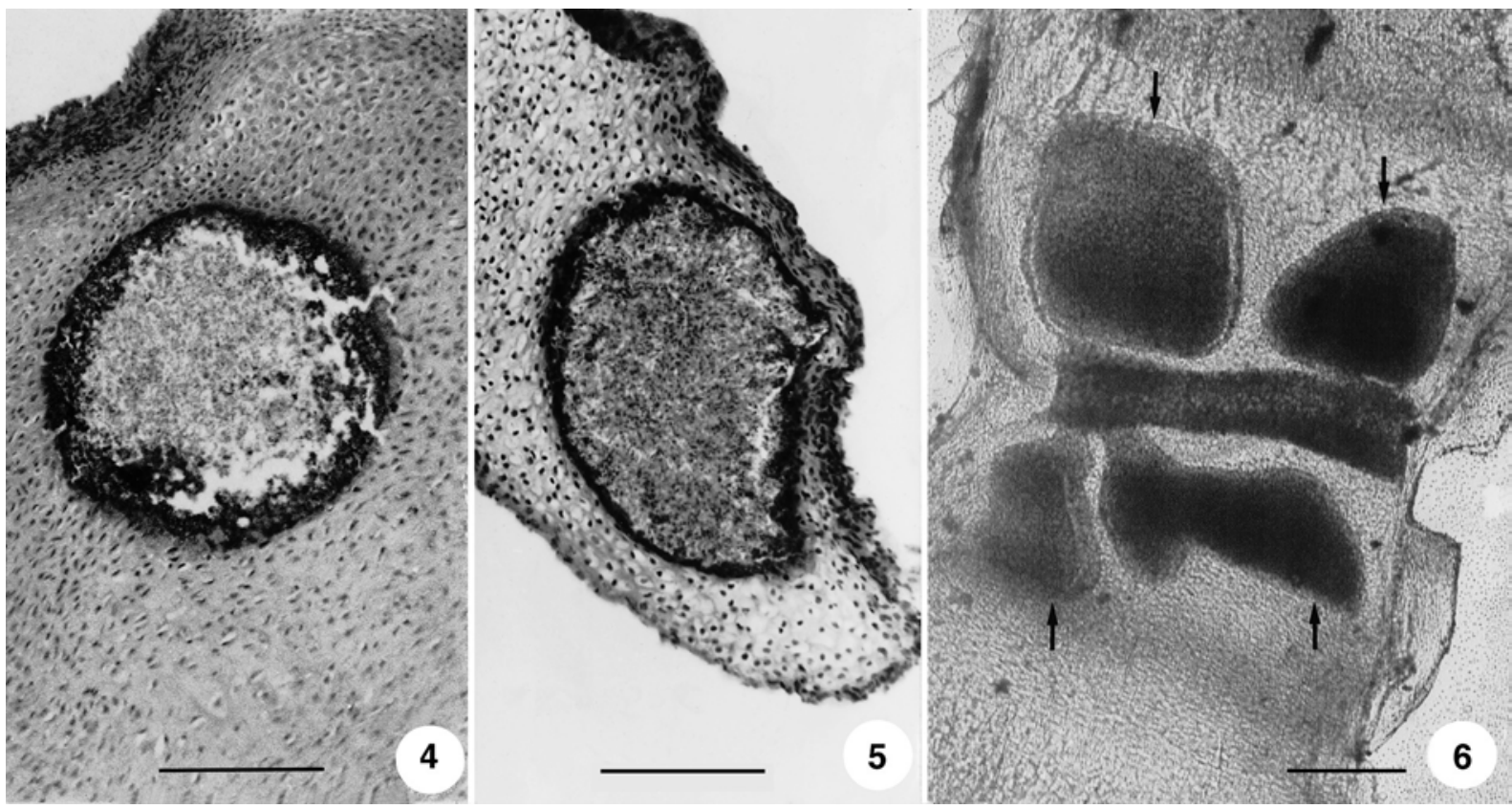

Fig. 4. Histological section of the cartilaginous end of a common carp gill arch containing a semi-mature plasmodium of Myxobolus intrachondrealis. The globular plasmodium inside the hyaline cartilage has mature spores in the centre and earlier developmental stages at the periphery. Haematoxylin and eosin (H\&E). Fig. 5. A more mature M. intrachondrealis plasmodium in the gill cartilage. The plasmodium is filled with spores. H\&E. Fig. 6. M. intrachondrealis plasmodia (arrows) in the joining parts of the central region of the gill arch. H\&E. Scale bars $=100 \mu \mathrm{m}$.

example of this is Myxobolus exiguus, which was originally described by Thélohan (1895) from two taxonomically very distant fish genera, the marine fishes Mugil chelo and M. capito and from the freshwater cyprinid species Abramis brama, and which was subsequently reported to have been detected by other authors from 25 additional fish species through identification merely on morphological grounds. However, Bahri and Marques (1996) characterised the parasites of Mugil cephalus previously identified as Myxobolus exiguus as four distinct host- and organspecific species. Similarly, it is difficult to identify the spores found in common carp with the already described but closely not studied Myxobolus species parasitising that fish species. Although the present author does not wish to increase the number of common carp parasitic Myxobolus species at all costs, he cannot identify with the known species such an expressly cartilage-parasitic species which differs from the formers also in its morphological characteristics. Although cartilaginous tissue is colonised by relatively few myxosporeans, it serves as a location for the best known Myxobolus species, M. cerebralis, and for $M$. cartilaginis, a species parasitising the gill cartilage of centrarchid fishes. According to the description by Hoffman et al. (1965), the plasmodia of the latter species develop in a fully identical manner as those of M. intrachondrealis, in islets surrounded by chondrocytes. Of the species parasitic in cyprinid fishes, Yokoyama et al. (1995) described Myxobolus cultus in experimentally infected goldfish: this species formed plasmodia in the cartilage of fins, neural spine and interneural spine. Another cartilage parasite is known from an Iranian barbel, Barbus sharpeyi: it was described by Molnár et al. (1996) by the name Myxobolus sharpeyi. Among the cartilage-parasitic Myxobolus species, M. cerebralis, M. cartilaginis and $M$. intrachondrealis equally possess spores lacking an iodinophilous vacuole and thus represent the Myxobolus type which was earlier classified into the "Myxosoma" genus. Myxobolus sharpeyi, in the spores of which Molnár et al. (1996) saw only a small, indistinct iodinophilous vacuole, can also be partially included in this category. On the other hand M. cultus, having a distinct iodinophilous vacuole, is a "typical Myxobolus". The presence of deformed, aged spores in a certain proportion of the plasmodia indicates that the multiple layers of surrounding chondrocytes impede the release of spores from the given location, and the spores can presumably leave the host only after the host has died and its tissues have disintegrated. The existence of such deformed spores also suggests that the description and identification of Myxobolus species should not be based exclusively on spore morphology. The majority of the currently known species have been described on the basis of spores released from plasmodia and 
disseminated throughout the body by the bloodstream. A certain proportion of these spores, especially those accumulating in the macrophage centres of the kidney, obviously represent damaged and deformed specimens. Therefore, during the revision of species the location of the parasite within the host and preferably also its tissue affinity should be taken into consideration besides the morphological characteristics recommended by Lom and Arthur (1989). Up to this time, identification of myxosporeans has been based on morphological variations in the spores. In the future, however, molecular biological methods, such as DNA techniques including PCR (Andree et al. 1999) might serve as an excellent tool for differentiation of morphologically similar species.

The results of the surveys indicate that the species described above is rather common in cultured common carp stocks in Hungary. Despite this fact, because of its unique isolated location the parasite is unlikely to have economic importance.

Acknowledgements. The author thanks Ms. Zsuzsa Kis for preparing histological slides, Dr. Gábor Majoros for offering Fig. 6, and Dr. Csaba Székely for his help with the video technique.

\section{REFERENCES}

ANDREE K.B., SZÉKELY C., MOLNÁR K., GRESOVIAC S.J., HEDRICK R.P. 1999: Relationship among members of the genus Myxobolus (Myxozoa: Bivalvidae) based on small subunit ribosomal RNA sequences. J. Parasitol. 85: 68-74.

AKHMEROV A.K. 1960: Myxosporidia of fishes of the Amur River Basin. Rybn. Khoz. Nutr. Vodoemov Latv. SSSR. 5: 239-308. (In Russian.)

BAHRI S., MARQUES A. 1996: Myxosporean parasites of the genus Myxobolus from Mugil cephalus in Ichkeul lagoon, Tunisia: description of two new species. Dis. Aquat. Org. 27: 115-122.

BAUER O.N., HOFFMAN G.L. 1976: Helminth range extension by translocation of fish. In: L.A. Page (Ed.), Wildlife Diseases. Plenum Publishing Corporation, New York, pp. 163-172.

BAUER O.N., VORONIN V.N., YUNCHIS O.N. 1991: Infection of the heart in carp caused by Myxobolus dogieli (Myxosporea, Myxobolidae). Angew. Parasitol. 32: 42-44.

CHEN C.-L. 1973: Illustrations of Fish Pathogens in Hubei Province. Science Publ. House, Peking, 456 pp. (In Chinese, with English abstract.)

DONEC Z.S., SHULMAN S.S. 1984: Parasitic protozoa. In: O.N. Bauer (Ed.), Key to Parasites of Freshwater Fish of the USSR. Vol. 1. Nauka, Leningrad, 426 pp. (In Russian.)

DYKOVÁ I., LOM J. 1988: Review of pathogenic myxosporeans in intensive culture of carp (Cyprinus carpio) in Europe. Folia Parasitol. 35: 289-307.

HOFFMAN G.L., PUTZ R.E., DUNBAR C.E. 1965: Studies on Myxosoma cartilaginis n. sp. (Protozoa: Myxosporidea) of centrarchid fish and a synopsis of the Myxosoma of North American freshwater fishes. J. Protozool. 12: 319-332.

HOSHINA T. 1953: On a new myxosporidian parasite Myxobolus dermatobius $\mathrm{n}$. sp. parasitic in the integument of Cyprinus carpio L. J. Tokyo Univ. Fish. 39: 209-213.

KUDO R.R. 1917: Contribution to the study of parasitic protozoa: II. Myxobolus toyamai nov. spec., a new myxosporidian in Cyprinus carpio. J. Parasitol. 3: 163-170.

LANDSBERG J.H., LOM J. 1991: Taxonomy of the genera of the Myxobolus/Myxosoma group (Myxobolidaesporea), current listing of species and revision of syno-nyms. Syst. Parasitol. 18: 165-186.

LOM J., ARTHUR J.R. 1989: A guideline for the preparation of species descriptions in Myxosporea. J. Fish Dis. 12: 151-156.

LOM J., DYKOVÁ I. 1992: Protozoan Parasites of Fishes. Development in Aquaculture and Fisheries Science, Vol. 26. Elsevier Science Publishers, Amsterdam, 315 pp.

LOM J., MOLNÁR K. 1983: Myxobolus basilamellaris sp. $\mathrm{n}$. (Myxozoa: Myxosporea), a parasite of the gills of common carp. Folia Parasitol. 30: 1-3.

MOLNÁR K. 1984: Comments on the host, organ and tissue specificity of fish myxosporeans and types of their intrapiscine development. Parasitol. Hung. 27: 5-20.

MOLNÁR K., KOVÁCS-GAYER É. 1981-1982: Occurrence of two species of Thelohanellus (Myxosporea: Myxozoa) of Far-Eastern origin in common carp populations of the Hungarian fish farms. Parasitol. Hung. 14: 51-54.

MOLNÁR K., KOVÁCS-GAYER É. 1985: The pathogenicity and development within the host fish of Myxobolus cyprini Doflein, 1898. Parasitology 90: 549-555.

MOLNÁR K., MASOUMIAN M., ABASI S. 1996: Four new Myxobolus spp. (Myxosporea: Myxobolidae) from Iranian barboid fishes. Arch. Protistenkd. 147: 115-123.

MOLNÁR K., SZAKOLCZAI J. 1980: Halbetegségek. Publ. House Mezõgazdasági, Budapest, 254 pp.

SZÉKELY C. 1997: Possible applications of video technology and digital image processing in fish parasitology: morphological examination of the groups Apicomplexa and Myxosporea-Actinosporea by video technology. Bull. Eur. Ass. Fish Pathol. 17: 81-82.

THÉLOHAN P. 1895: Recherches sur les Myxosporidies. Bull. Sci. Fr. Belg. 26: 100-394.

YOKOYAMA H., OGAWA K., WAKABAYASHI H. 1995: Myxobolus cultus n. sp. (Myxosporea: Myxobolidae) in the goldfish Carassius auratus transformed from the actinosporean stage in the oligochaete Branchiura sowerbyi. J. Parasitol. 81: 446-451.

YUKHIMENKO S.S. 1986: New species of Myxosporidia of the genus Myxobolus (Myxosporidia: Myxobolidae) from Cyprinidae of the Amur River. Parazitologiya 20: 416421. 